\title{
Helminth eggs with zoonotic potential in the vicinity of public schools in southern Brazil
}

\author{
Ovos de helmintos com potencial zoonótico nas proximidades de \\ escolas públicas no extremo sul do Brasil \\ Catia Cilene Santos de Mello ${ }^{1}$, Leandro Quintana Nizoli², Alexsander Ferraz², \\ Bruno Cabral Chagas ${ }^{1}$, William James Domingues Azario ${ }^{3}$, Marcos Marreiro Villela1* (D) \\ 1 Departamento de Microbiologia e Parasitologia, Instituto de Biologia, Universidade Federal de Pelotas - UFPel, Pelotas, RS, Brasil
2 Departamento de Veterinária Preventiva, Faculdade de Veterinária, Universidade Federal de Pelotas - UFPel, Pelotas, RS, Brasil
${ }^{3}$ Secretaria Municipal de Educação e Desporto, Prefeitura Municipal de Pelotas, Pelotas, RS, Brasil
}

How to cite: Mello CCS, Nizoli LQ, Ferraz A, Chagas BC, Azario WJD, Villela MM. Helminth eggs with zoonotic potential in the vicinity of public schools in southern Brazil. Braz J Vet Parasitol 2020; 29(1): e016419. https://doi.org/10.1590/S1984-29612019102

\begin{abstract}
The aim of this study was to evaluate environmental contamination by helminth eggs with zoonotic potential that were found in dog feces in the vicinity of elementary schools. Seventy-nine samples of dog feces were collected from 28 municipal schools located in five neighborhoods in Pelotas, Rio Grande do Sul (RS), Brazil. The samples were processed using the Willis-Mollay technique and analyzed using an optical microscope (40X), to identify any parasite eggs present. All neighborhoods were positive and $74.7 \%$ of the samples exhibited one or more helminth genera. The agent with the highest prevalence was Ancylostoma spp. (93.2\%), followed by Trichuris spp. (18.6\%), Toxocara spp. (11.9\%) and Toxascaris (1.7\%). These data show that there is a need for greater care towards controlling these helminths with zoonotic potential, including responsible pet ownership and daily activities to clean and collect dog feces in the vicinity of schools, because these are places where children play and study.
\end{abstract}

Keywords: Environmental contamination, larva migrans, hookworms, Toxocara spp.

\section{Resumo}

O objetivo deste estudo foi avaliar a contaminação ambiental por ovos de helmintos com potencial zoonótico, diagnosticados em fezes caninas depositadas nas proximidades de escolas primárias. Setenta e nove amostras de fezes foram colhidas em 28 escolas municipais localizadas em cinco bairros da cidade de Pelotas, Rio Grande do Sul (RS), Brasil. As amostras foram processadas pela técnica de Willis-Mollay e analisadas em microscópio óptico (40X), para identificar quaisquer parasitos presentes. Todos os bairros foram positivos e $74,7 \%$ das amostras apresentaram um ou mais gêneros de helmintos. O agente com maior prevalência foi Ancylostoma spp. (93,2\%), seguido por Trichuris spp. (18,6\%), Toxocara spp. (11,9\%) e Toxascaris (1,7\%). Esses dados mostram que há necessidade de maior cuidado no controle desses helmintos com potencial zoonótico, incluindo a posse responsável dos animais e atividades diárias de limpeza e colheita de fezes de cães nas proximidades das escolas, porque esses são locais onde as crianças brincam e estudam.

Palavras-chave: Contaminação ambiental, larva migrans, ancilostomídeos, Toxocara spp. 
Close relationships between humans and domestic animals such as dogs and cats do not just become established in households. These animals also frequent public spaces that are used for leisure activities, especially by children, who thus are exposed to the risk of infection caused by some helminth species (Carvalho \& Rocha, 2011).

Dogs and cats are the domestic animals that maintain closest the contact with humans. Consequently, sanitary control regarding these animals is essential for human health. Among the diseases that affect dogs and cats, gastrointestinal helminthiases require attention within veterinary practice and public health promotion (Acha \& Szyfres, 2003; Hotez et al., 2008; Peruca et al., 2009). These parasitoses may lead to anemia, diarrhea, weight loss, enteritis and even dogs' and cats' death (Robertson \& Thompson, 2002). Humans may also contract them when they have direct contact with these animals, drink/eat water/food contaminated by parasite eggs or are affected by active larval penetration through the skin. Cutaneous larva migrans (CLM) and visceral larva migrans (VLM) are among the infections that are transmitted to humans by dogs and cats (Santarém et al., 2004; Mendonça et al., 2013; Moura et al., 2013).

Since these parasitoses can have an impact on both human and animal health, it is fundamental to monitor areas where there are many domestic, semi-domestic and stray dogs, so as to evaluate the risks that they pose to the community. Therefore, the aim of this study was to evaluate environmental contamination by zoonotic agents in dog feces collected in the vicinity of elementary schools.

Samples of dog feces were collected within a radius of 50 meters from the entrance gate of every municipal elementary school located in five neighborhoods in Pelotas, Rio Grande do Sul (RS), Brazil. They were stored in plastic bags and kept under refrigeration at $4^{\circ} \mathrm{C}$ until the time of processing at the Laboratory of Parasitic Diseases (LADOPAR), which belongs to the School of Veterinary Sciences at the Federal University of Pelotas (UFPel). Parasite eggs were evaluated using the modified Willis technique (Willis, 1921) and their morphological characteristics were identified using an optical microscope (40X objective lens).

The results were expressed as descriptive statistics and were then tabulated and analyzed using the Microsoft Exce ${ }^{\circledR}$ software. The chi-square test $\left(\chi^{2}\right.$ test) was used to ascertain whether any statistically significant differences were present among the variables (feces, neighborhoods and distances between schools). P-values $\leq 0.05$ were considered significant.

Twenty-eight (84.8\%) out of the 33 schools that were investigated between March and September 2017 presented dog feces in their vicinity. Most of these schools (23) were located on the outskirts of the city, while five were downtown. Data provided by the Municipal Department of Education and Sports (SMED) showed that the schools under investigation represented $80.5 \%$ of the schools located in the urban area and had 20,812 students enrolled (Table 1).

Table 1. Number of schools and their students in neighborhoods under investigation in Pelotas, RS, Brazil.

\begin{tabular}{ccc}
\hline Neighborhood & \% of schools visited & \% of students enrolled \\
\hline Areal & $77.8 \%(7 / 9)$ & $84.3 \%(5012 / 5945)$ \\
\hline Centro & $85.7 \%(6 / 7)$ & $96.7 \%(5426 / 5613)$ \\
\hline Fragata & $100 \%(7 / 7)$ & $100 \%(4238 / 4238)$ \\
\hline Laranjal & $100 \%(3 / 3)$ & $100 \%(1913 / 1913)$ \\
\hline Três Vendas & $66.7 \%(10 / 15)$ & $52.4 \%(4223 / 8053)$ \\
\hline Total & $80.5 \%(33 / 41)$ & $80.8 \%(20812 / 25762)$ \\
\hline
\end{tabular}

Seventy-nine samples of feces were collected in the vicinity of the schools investigated; $74.7 \%$ of these samples exhibited one or more helminth genera. The lowest 
prevalence of contamination (60.0\%) was found downtown, while the highest (80.0\%) was found in a suburb called Areal. However, there were no significant differences among the neighborhoods regarding the frequency of findings of feces with parasites in the vicinity of the schools under investigation $(p \geq 0.05)$ (Table 2 ).

Table 2. Number of samples of helminth-positive feces in the vicinity of schools and their neighborhoods in Pelotas, RS, Brazil.

\begin{tabular}{ccccc}
\hline Neighborhood & No. of schools & $\begin{array}{c}\text { No. of stool } \\
\text { samples collected }\end{array}$ & $\begin{array}{c}\text { No. of helminth- } \\
\text { positive stool } \\
\text { samples }\end{array}$ & $\begin{array}{c}\text { \% of positive } \\
\text { samples }\end{array}$ \\
\hline Areal & 7 & 20 & 16 & 80.0 \\
\hline Centro & 5 & 10 & 6 & 60.0 \\
\hline Fragata & 5 & 10 & 7 & 70.0 \\
\hline Laranjal & 2 & 9 & 7 & 77.8 \\
\hline Três Vendas & 9 & 30 & 23 & 76.7 \\
\hline Total & 28 & 79 & 59 & 74.7 \\
\hline
\end{tabular}

Lower prevalences of contamination were reported by La Torre et al. (2018) in samples of dog feces in Rome and Padua, Italy (9.7\%), and by Medina-Pinto et al. (2018) in samples of dog feces collected from public parks in Yucatán, Mexico, where the positivity rate was only $11 \%$. In RS, Lopes et al. (2014) found positivity similar to what is reported in the present study, i.e. contamination by parasite eggs in $71.6 \%$ of feces samples collected from public squares in municipalities located in the south of RS. In the same state, Scaini et al. (2003) observed $86.1 \%$ positivity in feces samples collected from streets in Cassino, a neighborhood in the municipality of Rio Grande, RS, while Villela et al. (2009) found 54.3\% positivity in feces deposited on beaches located in Laranjal, in Pelotas, RS. The latter corroborate the data collected in the present study, since Laranjal was also evaluated in this study and exhibited contamination in $\mathbf{7 7 . 8 \%}$ of the feces samples (Table 2 ).

Table 3. Occurrence of monoparasitism and polyparasitism caused by helminths in samples of dog feces collected in the vicinity of schools in Pelotas, RS, Brazil.

\begin{tabular}{lcc}
\hline \multicolumn{1}{c}{ Parasite(s) } & $\begin{array}{c}\text { Absolute } \\
\text { frequency (\%) }\end{array}$ & $\begin{array}{c}\text { Relative } \\
\text { frequency (\%) }\end{array}$ \\
\hline Ancylostoma spp. & 41 & 69.5 \\
\hline Trichuris spp. & 3 & 5.1 \\
\hline Toxocara spp. & 1 & 1.7 \\
\hline Ancylostoma spp. + Trichuris spp. & 8 & 13.6 \\
\hline Ancylostoma spp. + Toxocara spp. & 5 & 8.5 \\
\hline Ancylostoma spp. + Trichuris spp. + Toxascaris spp. & 1 & 1.7 \\
\hline
\end{tabular}

In $76.3 \%$ (45/59) of the samples, one parasite genus was detected, while in $23.7 \%$ (14/59) of them, polyparasitism was observed (Table 3).

Regarding the method used in the present investigation, the Willis technique was chosen because it presents good results in environmental contamination studies, showing significant difference when compared to the Faust, Sedimentation and direct examination technique (Táparo et al., 2006). Moreover, such technique has lower material costs, shorter execution time and only requires the use of supersaturated solution (Novaes \& Martins, 2015). However, it should be noted that other authors have detected different results. According to Santana et al. (2015), the centrifugal flotation technique showed higher sensitivity towards detecting Ancylostoma spp. and Toxocara spp. 
in dog feces. Therefore, the use of only one technique may not reveal the total parasitism present in the samples, wich can be considered one of the limitations of this research.

Ancylostoma spp. was the most prevalent parasite, since it was found in $93.2 \%(55 / 59)$ of the positive samples ( $p 0.0001)$; followed by Trichuris spp., in 18.6\% $(11 / 59)$; Toxocara spp., in $11.9 \%$ (7/59); and Toxascaris spp., in 1.7\% (1/59). Similar distribution was reported by Scaini et al. (2003) in Cassino, a neighborhood and beach in Rio Grande, RS, where the percentage prevalences were $71.3 \%, 32.5 \%$ and $9.3 \%$, and by Villela et al. (2009) on the seashore in Laranjal, a neighborhood in Pelotas, RS, where they found $90 \%, 14.7 \%$ and 6.3\%, in the cases of Ancylostoma, Trichuris and Toxocara, respectively. Other studies carried out in different Brazilian regions also found that Ancylostoma spp. was the helminth with the highest prevalence (Blazius et al., 2005; Labruna et al., 2006; Katagiri \& Oliveira-Sequeira, 2008; Oliveira et al., 2009; Prates et al., 2009; Klimpel et al., 2010; Ferreira et al., 2013, 2016). Thus, precautions need to be taken since cutaneos larva migrans may be acquired in the vicinity of schools, given that the larvae of both Ancylostoma braziliense and Ancylostoma caninum have the capacity to penetrate through the skin (Bowman et al., 2010). Moreover, this is currently considered to be a neglected parasitic skin disease, and cutaneous larva migrans is one of the most common skin diseases reported in travelers returning from tropical regions (Leung et al., 2017; Reichert et al., 2018).

The possibility of Toxocara transmission, together with favorable environmental conditions, is a serious risk to public health (Capuano \& Rocha, 2006; Santos et al. 2017). The nematode Toxocara spp. is usually identified as the causative agent of visceral larva migrans and ocular larva migrans (Sviben et al., 2009), and it still may result in central nervous system alterations (Hotez, 2014). A study carried out by Schoenardie et al. (2013) in the same region found that the seroprevalence of $T$. canis in children in Pelotas, RS, was $50.6 \%$. These authors correlated their finding with the high rate of occurrence of stray dogs in this city (Schoenardie et al., 2013). Although no investigation of seroprevalence has been conducted among schoolchildren from the schools covered in this study, it is possible that a significant proportion of these individuals will be positive for anti-Toxocara canis antibodies, since parasite eggs have been identified in animal feces in the vicinity of the schools.

Concerning Trichuris spp. eggs, they may have belonged to the species Trichuris vulpis, which is a nematode that occurs in dogs, since dogs were often seen in the vicinity of these schools, even following children to the school gates. It should be highlighted that this finding requires attention because the zoonotic potential of $T$. vulpis has already been proven and its importance has been acknowledged, because this helminth may cause damage to digestive system (Traversa, 2011; Márquez-Navarro et al., 2012; Mohd-Shaharuddin et al., 2019).

Education for the population regarding hygiene measures and attention to the health of animals that are kept by the population not only enables changes in concepts and habits relating to zoonoses but also encourages responsible pet ownership. The importance of sanitary care for pets and responsible pet rearing in households needs to be emphasized, since lack of knowledge among the population regarding the risks involved in these diseases is one of the main factors that trigger these diseases (Peruca et al., 2009). From this, an educational folder about "environmental contamination by parasites and the importance of responsible pet ownership" was distributed to schools students.

There was high occurrence of helminth eggs with zoonotic potential in dog feces found in the vicinity of elementary schools in Pelotas, RS, Brazil. The results showed the role played by dogs in environmental contamination and emphasized the need for practices that prevent and control parasite infections. Such practices need to be implemented in association with responsible pet ownership and control over stray dogs, so as to decrease contamination in these areas and, consequently, decrease the population's exposure to these infections. 


\section{References}

Acha PN, Szyfres B. Zoonoses and communicable diseases common to man and animals: parasitoses. Washington: PAHO; 2003.

Blazius RD, Emerick S, Prophiro JS, Romão PRT, Silva OS. Ocorrência de protozoários e helmintos em amostras de fezes de cães errantes da cidade de Itapema, Santa Catarina. Rev Soc Bras Med Trop 2005; 38(1): 73-74. http://dx.doi.org/10.1590/S0037-86822005000100018. PMid:15717103.

Bowman DD, Montgomery SP, Zajac AM, Eberhard ML, Kazacos KR. Hookworms of dogs and cats as agents of cutaneous larva migrans. Trends Parasitol 2010; 26(4): 162-167. http://dx.doi.org/10.1016/j.pt.2010.01.005. PMid:20189454.

Capuano DM, Rocha GM. Ocorrência de parasitas com potencial zoonótico em fezes de cães coletadas em áreas públicas do município de Ribeirão Preto, SP, Brasil. Rev Bras Epidemio/ 2006; 9(1): 81-86. http://dx.doi.org/10.1590/S1415-790X2006000100010.

Carvalho EAA, Rocha RL. Toxocariasis: visceral larva migrans in children. J Pediatr 2011; 87(2): 100-110. http://dx.doi.org/10.1590/S0021-75572011000200004. PMid:21503372.

Ferreira FP, Dias RCF, Martins TA, Constantino C, Pasquali AKS, Vidotto O, et al. Frequência de parasitas gastrointestinais em cães e gatos do município de Londrina, $\mathrm{PR}$, com enfoque em saúde pública. Semina: Ciênc Agrár 2013; 34(6): 3851-3858. http://dx.doi.org/10.5433/16790359.2013v34n6Supl2p3851.

Ferreira JIGS, Pena HFJ, Azevedo SS, Labruna MB, Gennari SM. Occurrences of gastrointestinal parasites in fecal samples from domestic dogs in São Paulo, SP, Brazil. Rev Bras Parasitol Vet 2016; 25(4): 435-440. http://dx.doi.org/10.1590/s1984-29612016081. PMid:27925072.

Hotez PJ, Bottazzi ME, Franco-Paredes C, Ault SK, Periago MR. The neglected tropical diseases of latin America and the Caribbean: a review of disease burden and distribution and a roadmap for control and elimination. PLoS Neg/ Trop Dis 2008; 2(9): e300. http://dx.doi.org/10.1371/journal.pntd.0000300. PMid:18820747.

Hotez PJ. Neglected infections of poverty in the united states and their effects on the brain. JAMA Psychiatry 2014; 71(10): 1099-1100. http://dx.doi.org/10.1001/jamapsychiatry.2014.1045. PMid:25103827.

Katagiri S, Oliveira-Sequeira TCG. Prevalence of dog intestinal parasites and risk perception of zoonotic infection by dog owners in São Paulo State, Brazil. Zoonoses Public Health 2008; 55(8-10): 406-413. http://dx.doi.org/10.1111/j.1863-2378.2008.01163.x. PMid:18811905.

Klimpel S, Heukelbach J, Pothmann D, Ruckert S. Gastrointestinal and ectoparasites from urban stray dogs in Fortaleza (Brazil): high infection risk for humans? Parasitol Res 2010; 107(3): 713-719. http://dx.doi.org/10.1007/s00436-010-1926-7. PMid:20532563.

La Torre F, Di Cesare A, Simonato G, Cassini R, Traversa D, di Regalbono AF. Prevalence of zoonotic helminths in Italian house dogs. J Infect Dev Ctries 2018; 12(8): 666-672. http://dx.doi.org/10.3855/jidc.9865.

Labruna MB, Pena HFJ, Souza SLP, Pinter A, Silva JCR, Ragozo AMA, et al. Prevalência de endoparasitas em cães da área urbana do município de Monte Negro, Rondônia. Arq Inst Biol (Sao Paulo) 2006; 73(2): 183 193.

Leung AKC, Barankin B, Hon KLE. Cutaneous larva migrans. Recent Pat Inflamm Allergy Drug Discov 2017; 11(1): 2-11. http://dx.doi.org/10.2174/1872213X11666170110162344. PMid:28078983.

Lopes TV, Fernandes CPM, Michelon L, Hijano A, Félix SR, Schons SV, et al. Parasitas zoonóticos em fezes de cães de praças públicas em municípios da região sul do Rio Grande do Sul, Brasil. Rev Bras Hig Sanid Anim 2014; 8(2): 242-250.

Márquez-Navarro A, García-Bracamontes G, Álvarez-Fernández BE, Ávila-Caballero LP, Santos-Aranda I, DíazChiguer DL, et al. Trichuris vulpis (Froelich, 1789) infection in a child: a case report. Korean J Parasitol 2012; 50(1): 69-71. http://dx.doi.org/10.3347/kjp.2012.50.1.69. PMid:22451737.

Medina-Pinto RA, Rodríguez-Vivas RI, Bolio-González ME. Zoonotic intestinal nematodes in dogs from public parks in Yucatán, México. Biomedica 2018; 38(1): 105-110. http://dx.doi.org/10.7705/biomedica.v38i0.3595. PMid:29668139.

Mendonça LR, Figueiredo CA, Esquivel R, Fiacconed RL, Pontes-de-Carvalho L, Cooper P, et al. Seroprevalence and risk factors for Toxocara infection in children from an urban large setting in 
Northeast Brazil. Acta Trop 2013; 128(1): 90-95. http://dx.doi.org/10.1016/j.actatropica.2013.06.018. PMid:23845771.

Mohd-Shaharuddin N, Lim YAL, Hassan NA, Nathan S, Ngui R. Molecular characterization of Trichuris species isolated from humans, dogs and cats in a rural community in Peninsular Malaysia. Acta Trop 2019; 190: 269-272. http://dx.doi.org/10.1016/j.actatropica.2018.11.026. PMid:30500371.

Moura MQ, Jeske S, Vieira JN, Corrêa TG, Berne MEA, Villela MM. Frequency of geohelminths in public squares in Pelotas, RS, Brazil. Rev Bras Parasitol Vet 2013; 22(1): 175-178. http://dx.doi.org/10.1590/S1984-29612013000100034. PMid:24252968.

Novaes MT, Martins IVF. Avaliação de diferentes técnicas parasitológicas no diagnóstico de helmintoses caninas. Rev Bras Med Vet 2015; 37(Supl. 1): 71-76.

Oliveira VSF, Melo DPG, Fernandes PR, Schulze CMB, Guimarães MS, Silva AC. Ocorrência de helmintos gastrintestinais em cães errantes na cidade de Goiânia-Goiás. Rev Patol Trop 2009; 38(4): 279-283.

Peruca LCB, Langoni H, Lucheis SB. Larva migrans visceral e cutânea como zoonoses: revisão de leitura. Vet Zootec 2009; 16(4): 601-616.

Prates L, Pacheco LS, Kuhl JB, Dias MLGG, Araújo SM, Pupulin ART. Frequência de parasitos intestinais em cães domiciliados da cidade de Maringá, PR. Arq Bras Med Vet Zootec 2009; 61(6): 1468-1470. http://dx.doi.org/10.1590/S0102-09352009000600033.

Reichert F, Pilger D, Schuster A, Lesshafft H, Guedes de Oliveira S, Ignatius R, et al. Epidemiology and morbidity of hookworm-related cutaneous larva migrans (HrCLM): results of a cohort study over a period of six months in a resource-poor community in Manaus, Brazil. PLoS Neg/ Trop Dis 2018; 12(7): e0006662. http://dx.doi.org/10.1371/journal.pntd.0006662. PMid:30024875.

Robertson ID, Thompson RC. Enteric parasitic zoonoses of domesticated dogs and cats. Microbes Infect 2002; 4(8): 867-873. http://dx.doi.org/10.1016/S1286-4579(02)01607-6. PMid:12270734.

Santana BB, Silva TLB, Ramos RAN, Alves LC, Carvalho GA. Evaluation of different parasitological techniques for diagnosing intestinal parasites in dogs. Open J Vet Med 2015; 5(02): 19-24. http://dx.doi.org/10.4236/ojvm.2015.52003.

Santarém VA, Giuffrida R, Zanin GA. Larva migrans cutânea: ocorrência de casos humanos e identificação de larvas de Ancylostoma spp. em parque público do município de Taciba, São Paulo. Rev Soc Bras Med Trop 2004; 37(2): 179-181. http://dx.doi.org/10.1590/S0037-86822004000200014. PMid:15094907.

Santos PC, Telmo PL, Lehmann LM, Lorenzi C, Hirsch C, Mattos GT, et al. Frequency of Toxocara spp. antibodies in umbilical cords of newborns attended at the University Hospital in Southern Brazil and factors associated with infection. Acta Trop 2017; 170: 43-47. http://dx.doi.org/10.1016/j.actatropica.2017.02.003. PMid:28188768.

Scaini CJ, Toledo RN, Lovatel T, Dionello MA, Gatti FA, Susin L, et al. Contaminação ambiental por ovos e larvas de helmintos em fezes de cães na área central do Balneário Cassino, Rio Grande do Sul. Rev Soc Bras Med Trop 2003; 36(5): 617-619. http://dx.doi.org/10.1590/S0037-86822003000500013. PMid:14576878.

Schoenardie ER, Scaini CJ, Brod CS, Pepe MS, Villela MM, McBride AJ, et al. Seroprevalence of Toxocara infection in children from southern Brazil.J Parasito/ 2013; 99(3): 537-539. http://dx.doi.org/10.1645/GE3182. PMid:23738711.

Sviben M, Cavlek TV, Missoni EM, Galinovic GM. Seroprevalence of Toxocara canis infection among asymptomatic children with eosinophilia in Croatia.J Helmintho/ 2009; 83(4): 369-371. http://dx.doi.org/10.1017/S0022149X09381213. PMid:19460194.

Táparo CV, Perri SHV, Serrano ACM, Ishizaki MN, Costa TP, Amarante AFT, et al. Comparação entre técnicas coproparasitológicas no diagnóstico de ovos de helmintos e oocistos de protozoários em cães. Rev Bras Parasitol Vet 2006; 15(1): 1-5. PMid:16646994.

Traversa D. Are we paying too much attention to cardio-pulmonary nematodes and neglecting oldfashioned worms like Trichuris vulpis? Parasit Vectors 2011; 4(1): 32. http://dx.doi.org/10.1186/1756-33054-32. PMid:21385441.

Villela MM, Pepe MS, Ferraz ML, Morais NCM, Araújo AB, Ruas JL, et al. Nota: contaminação ambiental da orla da Laguna dos Patos (Pelotas, RS, Brasil), por parasitos com potencial zoonótico. Vittalle 2009; 21(2): 69-74.

Willis HH. A simple levitation method for the detection of hookworm ova. Med J Aust 1921; 2(18): 375-376. http://dx.doi.org/10.5694/j.1326-5377.1921.tb60654.x. 